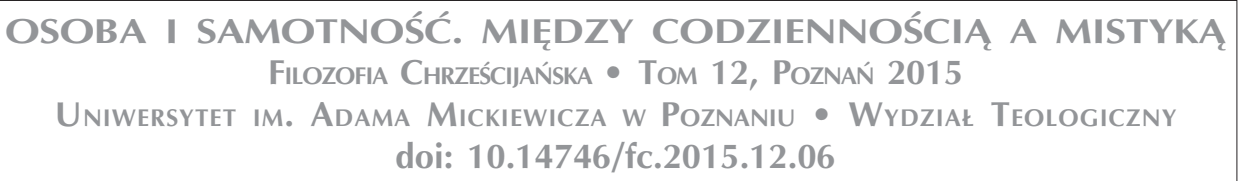

MAREK JĘDRASZEWSKI

Arcybiskup metropolita łódzki

\title{
Hipostaza, ateista i Sługa Jahwe, czyli trzy koncepcje samotności w filozofii Emmanuela Levinasa
}

\author{
Hypostasis, Atheist and the Servant of Yahweh, or Three Concepts of Solitude \\ in the Philosophy of Emmanuel Levinas
}

\section{WSTĘP}

Samotność człowieka może wydawać się czymś paradoksalnym. Nigdy przecież nie istnieje on w pojedynkę. Każdy, niekiedy aż nadto często, jest otoczony innymi osobami i rzeczami. Mimo to czasami doświadczamy samotności i bywa, że to doświadczenie jest bardzo bolesne.

Kiedy jednak mówimy o samotności, trzeba mieć świadomość także tego, że ma ona niejedno imię i niejeden kształt. Może to być bowiem samotność pośród całkowitej inności tego, co poza człowiekiem. W tym przypadku jest to samotność ocierająca się o tragiczność, mimo nadziei iż uda się człowiekowi z niej ostatecznie wydobyć. Może to być samotność będąca niezbędnym warunkiem osobistego wzrastania. Wtedy jawi się ona jako coś bardzo pozytywnego, wręcz jako szansa, by stać się w pełni kimś i by, następnie, móc zawiązać z innymi relacje interpersonalne. Może to być, na koniec, samotność przeznaczenia - jakiejś szczególnej roli czy zadania, które zostało komuś powierzone. Wówczas mamy do czynienia z pojedynczym bohaterem, który samotnie pełni jakąś misję wobec świata.

Jest rzeczą niezmiernie interesująca, że wszystkie te trzy koncepcje samotności możemy odnaleźć w filozofii Emmanuela Levinasa. Co więcej, odnalezienie ich nie sprawia nam większego trudu, $\mathrm{z}$ tego powodu że, po pierwsze, w jakiejś mierze samotność znajduje się w centrum jego filozofii oraz że, po drugie, w każdym z trzech okresów jego filozoficznej drogi ukazywana przez niego samotność przybiera odmienny kształt. W pierwszym okresie Levinas ukazuje nam 
samotność monady tragicznie zamkniętej w sobie samej. W drugim okresie kreśli przed nami obraz samotności jako transcendentalnego warunku zaistnienia spotkania z Innym. Natomiast w trzecim głosi samotność podmiotu bezgranicznie odpowiedzialnego za Innych. Dodać przy tym trzeba, że termin „samotność” (la solitude) pojawia się tylko w pierwszym okresie jego filozoficznych poszukiwań. W okresie drugim samotność jest określana przez niego mianem „separacji” (la séparation), by w okresie trzecim przyjąć imię „Sobości” (le Soi). Mimo że Levinas posługuje się tymi trzema odrębnymi terminami i że mogłyby one sugerować zupełnie odmienne rzeczywistości, to jednak zbiegają się one ze sobą właśnie w tym, co składa się na treściowe bogactwo doświadczenia samotności.

\section{SAMOTNOŚĆ ISTNIENIA}

Pierwszy okres w filozofii Levinasa - okres ontologiczny - zaznaczył się głównie przez dwa jego eseje: De l'existence à l'existant (Istniejacy $i$ istnienie) z 1947 roku oraz Le temps et l'autre (Czas $i$ to, co inne), który powstał jako zapis czterech wykładów wygłoszonych przez Levinasa w latach 1946-1947 w założonym przez Jeana Wahla Collège Philosophique. W esejach tych podjął on próbę ukazania samotności podmiotu, znajdując się wtedy pod, nieskrywanym zreszta, wpływem ontologicznej wizji świata zaprezentowanej przez Martina Heideggera w jego Sein und Zeit.

Zdaniem Levinasa, codzienność każdego człowieka wyznaczona jest przez ogromną liczbę spotkań i kontaktów z innymi rzeczami i osobami. Kontakty te mają charakter relacji całkowicie przechodnich, wyznaczonych przez czas. Od kontaktów z jednymi rzeczami czy osobami człowiek przechodzi po jakimś czasie do innych tego rodzaju kontaktów. Jednakże w głębi tej przechodniości znajduje się coś niezmiernie ważnego - coś, co ma charakter absolutnie nieprzechodni. Coś, co ciagle trwa. Jak stwierdza Levinas, ,jestem całkowicie sam. To zatem bycie we mnie [l'être en moi], fakt, że istnieję, moje istnienie [mon exister] stanowi element absolutnie nieprzechodni [intransitif], coś bez intencjonalności, bez odniesień. Wszystko można między bytami wymieniać oprócz istnienia [sauf l'exister]"'. Dla człowieka wynika stąd możliwość izolowania siebie na płaszczyźnie ontologicznej - i to przez samo jego istnienie. Nie chodzi więc tutaj o samotność w sensie psychologicznym lub socjologicznym, na wzór Robinsona na bezludnej wyspie, ani też o samotność „komunikacyjną”, wynikającą z niemożliwości przekazywania innym pewnych treści ze strony jakiejś świadomości. Mówiąc o samotności właśnie w sensie ontologicznym, Levinas nawiązał do języka

${ }^{1}$ E. Levinas, Czas i to, co inne, thum. J. Migasiński, Warszawa 1999, s. 24; por. tenże, Le temps et l'autre, Paris 2007, s. 21. W dalszej części artykułu esej Czas i to, co inne jest cytowany jako CI, natomiast Le temps et l'autre jako TA. 
monadologii Leibniza. „O ile jestem, jestem monada [je suis monade, en tant que je suis]. Jestem bez drzwi i okien właśnie przez istnienie, a nie dzięki jakiejkolwiek treści, która byłaby we mnie niekomunikowalna"”. To związanie się podmiotu $\mathrm{z}$ własnym istnieniem stanowi dla niego „relację par excellence wewnętrzną”, która polega na nierozerwalnej jedności „między istniejącym i jego urzeczywistnianiem istnienia [l'unité indissoluble entre l'existant et son oeuvre d'exister]"3.

Problem związania bytu z własnym byciem był przedmiotem zainteresowań Levinasa jeszcze przed II wojną światową. Ich owocem stał się obszerny esej z 1935 roku De l'évasion (O uciekaniu), w którym podjął on analizy dotyczące przyjemności (le plaisir), wstydu (la honte), wstydliwości (la pudeur) i mdłości (la nausée $)^{4}$. Po wojnie w eseju De l'existence à l'existant Levinas wzbogacił te refleksje o analizy związane z doświadczeniem zmęczenia (la fatigue), lenistwa (la paresse) i znużenia (la lassitude). Jednakże w stosunku do tych esejów w swej kolejnej publikacji, to znaczy w Le temps et l'autre, uczynił on jeden bardzo znaczący krok naprzód, usiłując ,ppoddać próbie samą zasadę związku pomiędzy istniejącym i jego istnieniem” i zbadać, ,czy ten związek [le lien] pomiędzy tym, kto istnieje [ce qui existe], i jego istnieniem [son exister], jest nierozerwalny"5. Aby odpowiedzieć na to pytanie, Levinas nawiązał do słynnej Heideggerowskiej różnicy ontologicznej między Sein (termin tłumaczony przez Levinasa jako exister - (istnienie) a Seiendes (termin oddawany przez Levinasa jako existant - (istniejący). Rozróżnienie to jest dla niego, z jednej strony, „najgłębszą rzeczą w Sein und Zeit", z drugiej jednak nie zostało ono doprowadzone do końca. U Heideggera bowiem relacja między Sein a Seiendes jest tylko rozróżnieniem, gdyż między nimi nie ma prawdziwej separacji (il y a distinction, il n'y a pas séparation $)^{6}$. Że natomiast taka separacja jest możliwa, wskazuje, zdaniem Levinasa, samo pojęcie Geworfenheit - „fakt-bycia-rzuconym-w...”. Jest w nim bowiem zawarta sugestia o tym, że istniejący pojawia się ,tylko w wyprzedzającym go istnieniu [dans une existence qui le précède]”. W konsekwencji należałoby powiedzieć również o jakimś ,istnieniu dziejącym się bez nas, bez podmiotu, o jakimś istnieniu bez istniejącego [un exister sans existant]"

Idąc za tą sugestią, Levinas przekroczył Heideggera i wprowadził pojęcie il y a jako „pole sił” istnienia (le „champ de forces” de l'exister), pole bezosobowe.

\footnotetext{
${ }^{2}$ CI, s. 24; por. TA, s. 21.

${ }^{3}$ Por. CI, s. 25, 25-26; por. TA, s. 21, 22.

${ }^{4}$ Tenże, De l'évasion, „Recherches Philosophiques” 5(1935-1936), s. 373-392; tenże, De l'évasion, Saint-Clément-de-Rivière (Fata Morgana) 1982; tenże, O uciekaniu, thum. A. Czarnacka, Warszawa 2007.

${ }^{5}$ Por. CI, s. 26; por. TA, s. 22-23.

${ }^{6}$ Por. CI, s. 27 ; por. TA, s. 24.

${ }^{7}$ Por. CI, s. 28; por. TA, s. 25.
} 
[...] Coś, co nie jest ani podmiotem, ani rzeczownikiem (ni sujet, ni substantif). Fakt istnienia, który się narzuca, kiedy nie ma już nic. I jest to anonimowe: nie ma nikogo ani niczego, co brałoby to istnienie na siebie. Jest to bezosobowe, jak wyrażenie „pada” albo ,jest ciepło”. Istnienie, które powraca niezależnie od negacji, poprzez którą by się je odrzucało. „Il y a” jako nieusuwalność czystego istnienia [l'irrémissibilité de l'exister pur] $]^{8}$.

Tej postaci istnienia Levinas nadał pewne wartościowanie o charakterze wyraźnie negatywnym, łącząc je z poczuciem absurdu, z którego nie można się wyrwać. „Bycie jest złem [l'être est le mal] nie dlatego, że jest skończone, lecz dlatego, że jest byciem bez granic" - stwierdził i zaraz odniósł to do Sein und Zeit: „Według Heideggera trwoga jest doświadczeniem nicości [du néant]. Czyż nie jest ona, przeciwnie - jeśli przez śmierć rozumie się nicość - faktem, że niemożliwe jest umrzeć?"’.

Mimo negatywnej oceny tej postaci istnienia, jaką jest il y $a$, tkwi w niej jednak pewna nadzieja. Jest ona bowiem „miejscem, w którym wytworzy się hipostaza [se produira l'hypostase ]" 10 , będąca drugą - w filozofii Levinasa - postacią istnienia. Polega ona na tym wydarzeniu ontologicznym, w którym istniejący „ściąga na siebie" istnienie. Dochodzi wtedy do zerwania przez świadomość z anonimowym czuwaniem il y a i do zaistnienia sytuacji, „w której istniejący wchodzi w związek ze swoim istnieniem [se met en rapport avec son exister]"11. W związku z tym ukazuja się jednocześnie dwie rzeczy. Po pierwsze, objawia się jakiś istniejący, który panuje nad własnym istnieniem. Po wtóre, dochodzi do procesu utożsamiania się tego kogoś. „Aby [...] mógł wystapić jakiś istniejący [un existant], musi stać się możliwe jakieś wyjście z siebie i jakiś powrót do siebie, to znaczy sama praca tożsamości [l'oeuvre même de l'identité]. Poprzez swoje utożsamienie istniejący zamyka się od razu w samym sobie; jest monadą i samotnością [monade et solitude]"12.

Będąc monada, to znaczy stając się świadomością siebie, stając się ,ja”, hipostaza zawiera w sobie jeszcze jeden niezmiernie ważny element. Istniejący jest bowiem „panem istnienia” (maître de l'exister), a w tym fakcie objawia się jego wolność, zwana przez Levinasa „pierwszą wolnością [première liberté]”.

Owa pierwsza wolność nie jest jeszcze wolnością wolnej woli [du libre arbitre], lecz wolnością zapoczątkowywania [la liberté du commencement]. Istnienie występuje teraz jako wychodzące od czegoś. Jest to wolność zawarta całkowicie w podmiocie, w samym fakcie, że jest podmiot [sujet], że jest byt [étant]. Wolność samego zawładnięcia istnieniem przez istniejącego ${ }^{13}$.

\footnotetext{
${ }^{8}$ CI, s. 30; por. TA, s. 26.

${ }^{9}$ CI, s. 34; por. TA, s. 29.

${ }^{10}$ CI, s. 33; por. TA, s. 28.

${ }^{11}$ Por. CI, s. 36; por. TA, s. 31.

${ }^{12}$ CI, s. 36-37; por. TA, s. 31-32.

${ }^{13}$ CI, s. 40-41; por. TA, s. 34.
} 
To zawładnięcie jest czymś pozytywnym, ponieważ jest momentem, w którym objawia się podmiot. Z drugiej jednak strony określa ona tworzącą się wówczas jego samotność. „Jest coś $\mathrm{w}$ istnieniu, poczynając od czego istnienie się tworzy”. Równocześnie jednak ,podmiot jest samotny, ponieważ jest jeden”"14. Levinas nie widzi w tym tylko elementów negatywnych. Są także pozytywne. „Samotność nie jest zatem tylko beznadzieją i opuszczeniem, ale także męstwem, dumą i suwerennością" - i na potwierdzenie tego przypomina on ,wątki literatury i psychologii romantycznej i byronicznej, dumnej [fière], arystokratycznej, wyniosłej [géniale]"15.

Jednakże ostatecznie w hipostazie przeważają elementy negatywne. Istniejący zajmuje się bowiem jedynie sobą - i na to zajmowanie się jest niejako skazany. Na tym polega to, co Levinas określa mianem materialności podmiotu, czyli przywiązaniem do siebie, koniecznością zajmowania się sobą, a przez to odpowiedzialnością za siebie. Wskutek tego sama wolność jest już nieuchronnie ograniczona przez odpowiedzialność za siebie. W tym objawia się „,cała materialność człowieka" - czyli wydarzenie ontologiczne polegające na pojmowaniu ciała począwszy od tej materialności, od tego związania Ja (Moi) z Sobością $(S o i)^{16}$. Od strony psychologicznej i antropologicznej wydarzenie to „wykłada się poprzez fakt, że ,ja” (le je) jest od razu przykute do siebie, że wolność owego ,ja” nie jest ulotna niczym łaska, lecz od razu jest ciążeniem, że Ja (le moi) jest nieuchronnie sobą $(s o i){ }^{\prime 17}$. Levinas nie waha się powiązać tej samotności ze swoistym tragizmem: „samotność jest tragiczna [...] dlatego, że jest zamknięta w niewoli swej tożsamości [dans la captivité de son identité], dlatego, że jest materią" ${ }^{18}$. Jednakże tragizm samotności nie stanowi jakiegoś uprzywilejowanego doświadczenia tego, co Heidegger określiłby mianem „bycia-ku-śmierci”. Zdaniem Levinasa, samotność idzie w parze z materialnością, co znajduje swe głębokie odbicie w życiu codziennym podmiotu. Stąd jest ona „towarzyszką powszechnej egzystencji stale nawiedzanej przez materię" i dlatego też ,życie codzienne [...] emanuje z naszej samotności, stanowi samo dopełnienie samotności i bezwzględnie poważną próbę odpowiedzi na jej głębokie nieszczęście [à son malheur profond]. Życie codzienne to troska o zbawienie [une préoccupation du salut]"19.

\footnotetext{
${ }^{14}$ CI, s. 42; por. TA, s. 35 .

${ }^{15}$ Por. CI, s. 42 , por. TA, s. 35.

${ }^{16} \mathrm{~W}$ swych dziełach Levinas pisze niekonsekwentnie małą lub dużą literą takie pojęcia, jak Inny (Autre), Drugi (Autrui) czy Sobość (Soi). W niniejszym artykule ukaże się to w thumaczeniach poszczególnych fragmentów tych dzieł. W części komentującej i przybliżającej myśl Levinasa terminy te pisane są konsekwentnie dużą literą.

${ }^{17}$ CI, s. 44; por. TA, s. 37.

${ }^{18}$ CI, s. 45-46; por. TA, s. 38.

${ }^{19}$ CI, s. 47-48; por. TA, s. 39.
} 


\section{SAMOTNOŚĆ JAKO SEPARACJA}

Głównym dziełem w drugim okresie filozoficznych poszukiwań Levinasa była książka Totalité et Infini (Całość i nieskończoność) z 1961 roku. Nawiązując do Kartezjańskiej idei Nieskończoności i wyciagając z niej strukturę formalną, próbował on ukazać możliwość zaistnienia relacji metafizycznej Ja (le Moi, le Même) z Innym (l'Autre), w której ten Inny, jawiący się także jako Drugi (l'Autrui), jest dla Ja Mistrzem i Nauczycielem, uczącym tegoż Ja autentycznej wolności oraz odpowiedzialności za Innych. Jednakże warunkiem wstępnym powstania relacji metafizycznej jest samo pojawienie się Ja. To zaś z kolei dokonuje się poprzez separację (la séparation). Jak stwierdzał Levinas, ,jest ona ostateczną strukturą bytu [la structure ultime], jakby samo wydarzania się [la production] jego nieskończoności. Społeczność [la société] spełnia ją w sposób konkretny"20. W powyższych dwóch zdaniach zostały nakreślone w sposób bardzo wyraźny dwie płaszczyzny, na których należy rozpatrywać problematykę separacji. Pierwszą z nich jest płaszczyzna metafizyczna, określona przez terminy „ostateczna struktura bytu” oraz „wydarzanie się jego nieskończoności”. Natomiast druga płaszczyzna dotyczy sposobu urzeczywistniania sie separacji w konkretnych relacjach miedzyosobowych.

Obydwie te płaszczyzny separacji zarysował Levinas w rozdziale IV części pierwszej książki Całość i nieskończoność, zatytułowanym „Separacja i Absolut”. Ukazując metafizyczną wartość separacji, odciął się on najpierw od długiej tradycji filozoficznej, sięgającej jeszcze czasów Parmenidesa i Plotyna, a w nowożytności naznaczonej przemyśleniami Spinozy i Hegla, która w sposób jednoznaczny przyznawała priorytet jedności i która uznawała separację i wewnętrzność za coś niepojętego i irracjonalnego. W myśl tej tradycji separacja wiązała się z potrzebą (le besoin), czyli z pewną pustką i brakiem występującymi u potrzebującego. Powyższej tradycji przeciwstawiała się inna, nawiązująca do Platona i do jego pojmowania Dobra, które jest transcendentne i które nie da się wyprowadzić z bytu. Platońskie Dobro łączy się z Pragnieniem (le Désir), charakteryzując relacje między takimi bytami, którym niczego nie brakuje, gdyż „posiadają własny byt”. Jak pisze Levinas, „Nieskończoność myślana konkretnie, to znaczy z perspektywy bytu oddzielonego, który się do niej zwraca, wychodzi poza siebie [se dépasse]. Inaczej mówiąc, otwiera porządek Dobra. [...] Separacja ustanawia samo myślenie i wewnętrzność, to znaczy relację niezależności (une relation dans l'indépendance)"21.

\footnotetext{
${ }^{20}$ Cytowany powyżej tekst odbiega w kilku miejscach od tłumaczenia Małgorzaty Kowalskiej. Podaję je w własnym, dosłownym tłumaczeniu, które, jak się wydaje, lepiej oddaje myśl Levinasa. Również w dalej cytowanych fragmentach Całości i nieskończoności odchodzę niekiedy od jej tłumaczenia. Por. tenże, Całość i nieskończoność, thum. M. Kowalska, Warszawa 1998, s. 110; por. tenże, Totalité et Infini, La Haye 1974, s. 75. W dalszej części artykułu książka Całość i nieskończoność jest cytowana jako CN, natomiast Totalité et Infini jako TI.

${ }^{21} \mathrm{CN}$, s. 112 ; por. TI, s. 77
} 
Tak konkretnie urzeczywistniająca się relacja międzyosobowa znajduje swój fundament w metafizycznej prawdzie o stworzeniu świata ex nihilo. Określając ją bliżej, Levinas pisze o „skurczeniu się” (une contraction) lub też o „stwórczym skurczu” (la contraction créatrice) Nieskończoności, „która wycofuje się z ontologicznej przestrzeni, by zostawić miejsce dla bytu oddzielonego"22. Jak się wydaje, Levinas nawiązuje tutaj do Izaaka Lurii i do centralnego pojęcia kosmogonicznego cimcum głoszonej przez niego Kabały. Według Hansa Jonasa,

Cimcum oznacza skurczenie się, cofnięcie, ograniczenie samego siebie. By użyczyć światu miejsca, En-Sof początku, Nieskończony, musiał się w sobie skurczyć i tym sposobem pozwolić na zewnątrz siebie powstać pustce, nicości, w której i z której mógł stworzyć świat. Bez tego cofnięcia się w samego siebie nie mogłoby istnieć nic na zewnątrz Boga; i tylko dzięki Jego dalszemu powściąganiu siebie dzieje się tak, że skończone rzeczy na powrót nie tracą swego bytu w Bożym byciu „wszystkim we wszystkim"”23.

Ponieważ owo skurczenie się Nieskończonego, by mógł powstać świat, wskazuje na Jego dobroć, to Levinas mógł powiedzieć, że „Nieskończoność otwiera porządek Dobra [l'Infini s'ouvre l'orde du Bien]"24. Jest to porządek naznaczony przez Pragnienie, charakteryzujące byty, którym niczego nie brakuje, a które jednak zawiązują między sobą relację. Nieskończonemu niczego przecież nie brakowało, a jednak skurczył się i sprawił, że świat zaczął istnieć. Stworzony przez Niego człowiek poprzez swoje z Nim obcowanie - poprzez religię - niejako odkupuje Stworzenie. „Stosunki, jakie zawiązują się między bytem oddzielonym a Nieskończonością [entre l'être séparé et l'Infini], odkupują to, co w stwórczym skurczu Nieskończonego mogło być umniejszeniem" ${ }^{25}$. W ten sposób powstaje możliwość „egzystencji sabatycznej”, w której istnieją niezależne wobec siebie byty, powiązane ze sobą nie przez potrzebę, lecz przez Pragnienie. Człowiek jest istotą stworzoną, nosi wprawdzie w sobie ślady zależności, będąc jednak istotą wolną, z tej relacji z Nieskończonym, z tej wyjątkowej zależności „czerpie samą swą niezależność, swoją zewnętrzność wobec systemu [son indépendance même, son extériorité au système]" ${ }^{\prime 26}$. Konkludując tę myśl, Levinas stwierdził: „Myślenie i wolność zawdzięczamy separacji i poszanowaniu Drugiego [Autrui] - ta teza leży na antypodach spinozyzmu".

Separacja, będąc niejako naznaczona przez Pragnienie, nie jest jednak negacją. Urzeczywistnia się ona bowiem jako psychika (comme psychisme $)^{27}$. To do-

22 Por. CN, s. 112-113; por. TI, s. 77.

${ }^{23}$ H. Jonas, Idea Boga po Auschwitz. Żydowski głos, w: tenże, Idea Boga po Auschwitz, thum. G. Sowinski, Kraków 2003, s. 45.

${ }^{24} \mathrm{CN}$, s. 113; por. TI, s. 77.

${ }^{25}$ Tamże.

${ }^{26} \mathrm{CN}$, s. 114; por. TI, s. 78.

${ }^{27}$ Por. tamże. 
konywanie się wskazuje na jeszcze jedną, trzecią już płaszczyznę analiz dotyczących separacji, w której chodzi o proces stawania się konkretnego bytu oddzielonego. Psychika wskazuje na pojedynczego człowieka, który staje się Ja, to znaczy bytem w pełni oddzielonym - a to przecież jest warunkiem zaistnienia relacji międzyosobowych, w tym także relacji z Nieskończonym.

Inność, radykalna heterogeniczność Innego [l'Autre], możliwa jest pod warunkiem, że Inne jest innym w stosunku do członu, który z istoty pozostaje w punkcie wyjścia, służąc za punkt wyjścia relacji, który jest Tym Samym [le Même] nie w sensie względnym, lecz w sensie absolutnym. Członem, który może pozostać absolutnie w punkcie wyjścia relacji, jest tylko $\mathrm{Ja}[\mathrm{Moi}]^{28}$.

Dodać tutaj należy jeszcze jedną uwagę: jeśli pierwsze dwie płaszczyzny, na których dokonuje się analiz dotyczących separacji, to znaczy metafizyczna i międzyosobowa, zostały określone przez Levinasa w jego dyskusji z najwybitniejszymi metafizykami starożytności i nowożytności, to płaszczyznę związaną z separacją jako wydarzaniem się psychiki można zrozumieć jako mniej lub bardziej wyraźną dyskusję z Husserlem.

$\mathrm{Na}$ tę dyskusję Levinasa wskazuje już sam punkt wyjścia dotyczący analiz konkretnego człowieka i jego relacji z tym, co inne. Nie jest nim bowiem Husserlowska świadomość intencjonalna, lecz doświadczenie samego życia. Jak pisze Levinas, ,prawdziwa i źródłowa [originelle] relacja między nimi, w której Ja odsłania się właśnie jako Ten Sam w ścisłym sensie, ma postać przebywania [séjour] w świecie. Sposób, w jaki Ja istnieje wobec „innego” świata, polega właśnie na przebywaniu [séjourner], na utożsamianiu się [s'identifier] przez istnienie $\mathrm{w}$ nim jak $u$ siebie $\left[\right.$ chez soi] ${ }^{\text {"29 }}$. To przebywanie $\mathrm{w}$ świecie i wynikające $\mathrm{z}$ niego utożsamianie się ze sobą, a więc niejako dzieło auto-separacji ze strony Ja, przyjmuje różne postaci: rozkoszowania się, domostwa, życia ekonomicznego. Jednak najbardziej widocznie dochodzi ono do głosu na poziomie pierwszym, czyli rozkoszowania się, o czym traktuje druga część książki Całość i nieskończoność, zatytułowana „Wewnętrzność i ekonomia”, tam gdzie Levinas w punkcie 3 pisze o „rozkoszowaniu się i separacji”, stwierdzając już w pierwszych jego fragmentach:

Być oddzielonym to być u siebie. Ale być u siebie to żyć czymś [c'est vivre de...], to używać w środowisku żywiołów [jouir de élémental]. „Porażka” świadomości dążącej do ukonstytuowania przedmiotów, którymi żyjemy [dont on vit], nie wynika z irracjonalnego charakteru lub mętności tych przedmiotów, lecz z ich funkcji - funkcji pożywienia [de nourritures]. Pokarm [l'aliment] nie jest nieprzedstawialny, lecz wykracza poza przedstawienie. A przecież to właśnie w nim Ja się odnajduje ${ }^{30}$.

${ }^{28} \mathrm{CN}$, s. 22; por. TI, s. 6. W odróżnieniu od tłumaczenia Małgorzaty Kowalskiej termin le Même jest tutaj thumaczony jako „Ten Sam”, a nie jako „Toż-Samy”.

${ }^{29} \mathrm{CN}$, s. 23 ; por. TI, s. 7.

${ }^{30} \mathrm{CN}$, s. 167 ; por. TI, s. $120-121$. 
W odróżnieniu od Husserla Levinas przyznaje zatem wyraźne pierwszeństwo samego ludzkiego życia wobec świadomości intencjonalnej podmiotu. Jeśli bowiem dla Husserla relacją pierwotną była relacja czystego Ja z przedmiotem, do którego docierała świadomość, to dla Levinasa źródłową relacją jest relacja żyjącego człowieka z niedającym się przedstawić przez świadomość intencjonalną pokarmem. Inaczej mówiąc, dla Husserla najważniejsza była „świadomość czegoś”, natomiast dla Levinasa „życie czymś”. Ponadto świadomość czegoś zakłada w sobie jakiś dystans między podmiotem a przedmiotem, podczas gdy życie czymś jest naznaczone szczególnym rysem, jakim jest rozkoszowanie się (la jouissance $e^{31}$ ), które charakteryzuje się bezpośredniością między człowiekiem rozkoszującym się pożywieniem a samym pożywieniem. Ja właśnie w nim odnajduje się i tworzy, tym bardziej że wraz z rozkoszowaniem idzie w parze szczęście (le bonheur). Ono jest ,zasadą indywiduacji”, którą należy pojmować nie od zewnątrz (jakby chciał tego Husserl ze swoją świadomością intencjonalną), lecz od wewnątrz, czyli z samej głębi żyjącego człowieka. „Wewnętrzność rozkoszowania się [l'intériorité de la jouissance] jest separacją samą w sobie. [...] Rozkoszowanie się jest właściwym wydarzaniem się bytu, który się rodzi, który rozdziera spokojną wieczność swojego embrionalnego istnienia, by powstać jako osoba [une personne]; który żyjąc światem, żyje u siebie [vit chez soi]" ${ }^{2}$. Separację Ja poprzez rozkoszowanie się pożywieniem, a przez to światem, wyraża Levinas również przez inne jeszcze określenia, które są dla niego synonimami: indywiduacja (l'individuation), autopersonifikacja (autopersonification), substancjalizacja (la substantialisation), niezależność Ja (l'indépendance du soi), egoizm (egoïsme), bycie sobą (être moi), bycie ateistą (être athée), bycie u siebie (être chez soi), bycie szczęśliwym (être heureux), bycie stworzonym (être créée) ${ }^{33}$.

Powstanie bytu oddzielonego, czyli czującego (sentant) - a nie, jak by to było u Husserla, intencjonalnego - jest warunkiem powstania i utworzenia się relacji metafizycznej Ja z Innym. Nie może to być jednak oddzielenie tak daleko idące, iżby ten Inny nie mógł zwrócić się i przemówić do Ja. Odwołując się do języka Leibniza, wewnętrzności Ja, o której mówi Levinas, nie można utożsamiać z monadą „,bez drzwi i okien”.

Zamknięcie bytu oddzielonego musi być więc dość dwuznaczne, by, z jednej strony, wewnętrzność konieczna dla idei Nieskończoności pozostawała rzeczywista [réelle], a nie tylko pozorna [apparente], by los wewnętrznego bytu dokonywał się w egoistycznym ateizmie [dans un athéisme égoïste], którego nie zakłóca żadna zewnętrzność. [...] Ale z drugiej strony $w$ samej wewnętrzności, jaką tworzy rozkoszowanie się, musi pojawiać się heteronomia, która zaprasza do innego losu [à un autre destin]

${ }^{31}$ Słowo la jouissance rozkoszowanie się, używanie pochodzi od czasownika jouir - rozkoszować się, używać, co wywodzi się z łacińskich słów fruitio i fruire.

${ }^{32} \mathrm{CN}$, s. 168; por. TI, s. 121.

${ }^{33}$ Por. CN, s. 168-169; por. TI, s. 121. 
niż to zwierzęce zadowolenie $\mathrm{z}$ siebie [complaisance animale en soi]. [...] Wewnętrzność musi być jednocześnie zamknięta i otwarta. Na tym właśnie polega możliwość wyrwania się z kondycji zwierzęcia [de la condition animale ${ }^{34}$.

Jest to niezmiernie ważny moment w Levinasowej koncepcji bytu oddzielonego. Takim musi on jako człowiek się stać - jako warunek transcendentalny relacji metafizycznej. Takim natomiast nie może pozostać - pod groźbą trwania jedynie w „kondycji zwierzęcia”, szczęśliwego z rozkoszowania się pożywieniem, i na tym rozkoszowaniu się poprzestając. Samotność człowieka jako bytu oddzielonego jest więc w jakiejś mierze - i na szczęście! - niepełna w swej definitywności. W schodzeniu człowieka „W siebie po zboczu przyjemności [sur la pente du plaisir] [...] musi [bowiem] pojawić się wyrwa [un heurt], która, choć nie odwraca kierunku interioryzacji, choć nie rozrywa splotu [la trame] wewnętrznej substancji, stanowi okazję do nawiązania stosunków z zewnętrznością" "35. Inaczej mówiąc, szczęście rozkoszowania się może być zakłócone przez niepokój, przez „troskę o jutro” (le souci du lendemain) - i to stanowi, według Levinasa, istotę różnicy między zwierzęciem a człowiekiem. Tę różnicę wyraził on w inny jeszcze sposób, tym razem odwołując się do języka Kanta, gdy byt oddzielony w swej samotności, a zatem pozostający przez rozkoszowanie się światem i pożywieniem na poziomie kondycji zwierzęcej, określił mianem „egzystencji fenomenalnej”, a człowieka odpowiadającego na słowo Innego „bytem w sobie”: „Wyjście poza egzystencję fenomenalną [l'existence phénoménale] lub wewnętrzną nie polega na byciu uznanym przez Drugiego [Autrui], ale na ofiarowaniu mu własnego bytu. Być w sobie [être en soi] to wyrażać się, a zatem służyć już drugiemu [autrui]. Na dnie ekspresji leży dobroć [la bonté]. Być $\kappa \alpha \theta$ '

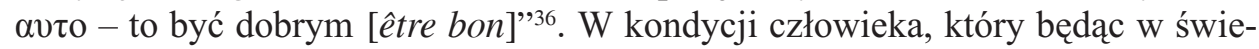
cie u siebie, jest ateista, zawarta jest zatem błogosławiona możliwość stanięcia twarzą w twarz wobec transcendencji Innego. Jak stwierdził Levinas, „w wewnętrzności otwiera się wymiar, dzięki któremu będzie ona mogła oczekiwać i przyjmować objawienie transcendencji [la révélation de la transcendance]" ${ }^{37}$. Wtedy to szczęście rozkoszowania się światem zostaje przewyższone przez Pragnienie Innego.

\section{SAMOTNOŚĆ WYBRANIA I PRZEZNACZENIA}

Jednym z kluczowych pojęć trzeciego okresu filozoficznej drogi Levinasa jest pojęcie Sobości (le soi). Zajmuje ono poczesne miejsce w najważniejszym jego dziele Autrement qu'être ou au-delà de l'essence (Inaczej niż być lub ponad

\footnotetext{
${ }^{34} \mathrm{CN}$, s. 170 ; por. TI, s. $122-123$.

${ }^{35} \mathrm{CN}$, s. 170; por. TI, s. 123.

${ }^{36} \mathrm{CN}$, s. 215; por. TI, s. 158.

${ }^{37} \mathrm{CN}$, s. 172; por. TI, s. 124.
} 
istota) - $\mathrm{i}$ to do tego stopnia, że taki właśnie tytuł nosi punkt 3 rozdziału IV „Substytucja". Pojęcie to jest nierozerwalnie związane z jeszcze innym: z l'obsession, które Piotr Mrówczyński oddaje jako „nawiedzenie”. Jest to thumaczenie, które może się wydać dość zaskakujące, ponieważ wyraz l'obsession znaczy przede wszystkim (obsesja), a polskie (nawiedzenie) zapewne w pierwszym znaczeniu to francuskie la visitation. Tymczasem Levinas, używając terminu l'obsession, ma na uwadze tak głębokie naznaczenie człowieka przez Dobro, że jest on przez nie niejako „nawiedzony”, wręcz „opętany” (mówimy niekiedy o kimś, że jest opętany przez jakąs ideę), że ta idea jest jego obsesją. Stąd tłumaczenie Mrówczyńskiego daje się niewątpliwie wybronić, niemniej jednak kiedy spotykamy się z terminem l'obsession u Levinasa, trzeba mieć na uwadze wszystkie odcienie znaczeniowe, o których była mowa powyżej. Dodać należy i to, że w samym już tym terminie jest mowa o samotności i wyjątkowości (pozytywnej lub negatywnej): nawiedzonym, opętanym, mającym obsesję czegoś jest jakiś zdecydowanie odbiegający od innych - a zatem w gruncie rzeczy bardzo samotny - człowiek.

Mówiąc o nawiedzeniu ${ }^{38}$, Levinas wskazuje najpierw na bierność, która jest bardziej bierna niż bierność rzeczy (passivité plus passive que celle des choses). Próbując ją przybliżyć, odwołał się on do pojęcia materii pierwszej, którą Logos wzywa, by nabrała upragnionych przez niego cech i ukazała się jako taka, a nie inna rzecz. Wyzwanie jest wezwaniem do kogoś wyrażonym w bierniku. Ta forma gramatyczna $\mathrm{w}$ języku francuskim nosi miano l'accusatif (od łac. accusativus), stąd rodzi się skojarzenie, do którego w pełni świadomie odwołuje się Levinas, z l'accusation - $\mathrm{z}$ oskarżeniem. Wezwany - i nawiedzony - jest jednocześnie oskarżonym. „Logos, który nadaje kształt materii pierwszej, przywołując ją do porządku [à l'ordre], jest ustanowieniem w bierniku, oskarżeniem [accusation] lub kategorią" ${ }^{39}$. Jednakże to oskarżenie jest anarchiczne, to znaczy dokonane jeszcze przed czasem, czyli przed jakąkolwiek możliwością, by świadomie na to wybranie-oskarżenie odpowiedzieć. Nawiązując do Arystotelesa i jego materii pierwszej, Levinas zwrócił uwagę na to, że materia ta, będąc in potentia, ,jest jeszcze moca, którą forma bierze pod uwagę" i dlatego jest ona przyczyna. Właśnie w takich kategoriach ontologicznych, ,to znaczy w związku z pewną niezniszczalną i preegzystującą materią" niektórzy filozofowie zachodni patrzyli na dzieło stworzenia. Tymczasem, według Levinasa, stworzenie człowieka należy pojmować w ten sposób, że Logos oskarża - i w ten sposób ustanawia, stwarza - podmiot „ponad materią pierwszą [en deça de la matière première]".

${ }^{38} \mathrm{~W}$ dalszym ciagu tego tekstu Levinasowe l'obsession będzie thumaczone - za Piotrem Mrówczyńskim - jako „nawiedzenie”, choć w innych cytowanych fragmentach Autrement qu'être, nasze thumaczenie będzie niekiedy odbiegać od tego, które jest zawarte w Inaczej niż być lub ponad istota. Por. E. Levinas, Autrement qu'être ou au-delà de l'essence, La Haye 1974; tenże, Inaczej niż być lub ponad istota, thum. P. Mrówczyński, Warszawa 2000. Dalej dzieło Autrement qu'être jest dalej cytowane jako AE, natomiast Inaczej niż być lub ponad istota jako IB.

${ }^{39} \mathrm{IB}$, s. 185 ; por. AE, s. 140. 
W nawiedzeniu [dans l'obsession] oskarżenie [l'accusation] ustanowione przez kategorię przekształca się w biernik absolutny [un accusatif absolu], w oskarżenie pod adresem ja wolnej świadomości [le moi de la conscience libre]: oskarżenie zapewne bezzasadne, wcześniejsze od wszelkich przejawów woli, oskarżenie obsesyjne i prześladujące [obsessionnelle et persécutrice]. [...] W bierniku podmiot zostaje „sprowadzony do siebie" [, en réduit à soi"], a tym samym nieuwarunkowany [sans condition $]^{40}$.

W tym sensie podmiot nie jest, według Levinasa, jakimś Ja (le Moi - to znaczy kimś w mianowniku), lecz jest od razu Sobością (le Soi - kimś w bierniku) i stąd owa Sobość jest właściwym imieniem podmiotu. „Od początku wszystko jest w bierniku [tout est au préalable à l'accusatif] - jest to wyjątkowy warunek lub bezwarunkowość sobości (du soi), znaczenie zaimka Sie (Se), którego mianownik „nie znany jest” nawet naszym łacińskim gramatykom”41.

Tak pojmowany podmiot nie jest bynajmniej jaką́s Arystotelesowską formą czy Husserlowskim czystym Ja. To człowiek z krwi i kości, ktoś, kto „w swojej skórze [dans sa peau]" jest nawiedzony, czyli ktoś, kto we własnej cielesności i poprzez nią urzeczywistnia siebie jako Sobość. To urzeczywistnianie siebie ze strony Sobości idzie niejako w dwóch kierunkach. Pierwszy polega na skierowaniu się Sobości do siebie, które sprowadza się, paradoksalnie, do swoistego wywłaszczania siebie, do nieustannego pozbawiania się spokoju bycia u siebie. „Nie spoczywając w jakiejś formie, ale wciśnięty we własną skórę, przepełniony i niejako zapchany samym sobą, duszący się pod soba, niewystarczająco otwarty, zmuszony do rozłączenia się ze sobą [à se dé-prendre de soi], do wzięcia głębszego oddechu, do końca, do wy-właszczenia się [à se dé-posséder] aż po zatracenie siebie" ${ }^{\$ 2}$. Natomiast drugi kierunek urzeczywistniania siebie jest zdążaniem Sobości w stronę Drugiego, za którego - na mocy anarchicznego naznaczenia przez Dobro - jest ona nieskończenie odpowiedzialna. Nieskończenie do tego stopnia, że podmiotowość podmiotu sprowadza się do bycia Innego w samych głębiach Ja.

Podmiotowość jako inny w tym samym [l'autre dans le même] - jako natchnienie [comme inspiration] - jest kwestionowaniem wszelkiej afirmacji „dla siebie” [,pour soi"], wszelkiego egoizmu odradzającego się nawet w cofaniu. [...] Podmiotowość podmiotu [la subjectivité du sujet] jest odpowiedzialnością lub byciem-zakwestionowanym jako całkowite odsłonięcie się na zniewagę policzka nadstawionego w stronę tego, który uderza ${ }^{43}$.

Konsekwencją tego skierowania ku Drugiemu jest nie tylko bierność jako bierność podmiotu niejako wydanego Drugiemu, ale bierność prześladowana.

\footnotetext{
${ }^{40}$ Tamże.

${ }^{41}$ IB, s. 188; por. AE, s. 143.

${ }^{42}$ IB, s. 185-186, por. AE, s. 140-141.

${ }^{43}$ IB, s. 187, por. AE, s. 141-142.
} 
Sobość cierpi przez (par) Drugiego, z tym że owo „przez” jest równocześnie cierpieniem za (pour) Drugiego. Inny jest bowiem nie tylko sprawcą cierpienia Sobości, ale jest także tym, za którego Sobość jest odpowiedzialna - także za cierpienia, których ten Drugi jest sprawcą. Bezinteresowność odpowiedzialności za niego osiaga w tym swój szczyt. Jest, jak pisze Levinas, substytucją. „Podmiot jest zakładnikiem [otage]" - i w tym byciu zakładnikiem Drugiego osiaga swą jedyność i niepowtarzalność poprzez to, że doznawane prześladowanie staje się odpokutowaniem za jego winy. „Jedyność sobości [l'unicité de soi] polega na dźwiganiu winy drugiego człowieka. [...] Stanie w bierniku, czyli oskarżenie można sprowadzić do bierności Sobości [à la passivité du Soi] tylko wtedy, gdy jest prześladowaniem [persécution], ale też prześladowaniem, które obraca się w odpokutowanie [en expiation]"44.

Powyższe sformułowania zdecydowanie odbiegają od powszechnie stosowanego języka filozofii. Zwłaszcza w Autrement qu'être, choć zdarzało się to już i w innych publikacjach, Levinas przeplata wyrażenia stricte filozoficzne $\mathrm{z}$ wyrażeniami sugerującymi niektóre fragmenty Biblii - a zatem z językiem religijnym. Dostrzec to można zwłaszcza w odniesieniu do tych jego usiłowań, poprzez które chciał wyrazić niezwykły status Sobości. Najpierw odnosi się to do samego tego pojęcia (le Soi). W pewnym fragmencie Autrement qu'être mamy bowiem do czynienia początkowo z tekstem ściśle filozoficznym: „Podmiotowość podmiotu jest byciem-poddanym-wszystkiemu [être-sujet-à-tout], pra-źródłową podatnością [susceptibilité pré-originaire] poprzedzającą wszelką wolność i wykraczającą poza wszelką teraźniejszość czy obecność; podmiotowością w niedogodności i nieuwarunkowaniu biernika [de l'accusatif]", który nagle przechodzi w tekst nasycony wyrażeniami religijnymi i kończący się przypisem odsyłającym do Księgi Izajasza: „w «oto jestem» [«me voici»], w posłuszeństwie chwale Nieskończonego [à la gloire de l'Infini], która podporządkowuje mnie Drugiemu człowiekowi [à Autrui]" ${ }^{45}$. Podobnie ma się rzecz z pojmowaniem Sobości poprzez prymat Cierpiącego Sługi Jahwe. $Z$ jednej strony natrafiamy na passusy „filozoficzne”:

Staramy się tutaj wypowiedzieć nieuwarunkowanie [l'incondition] podmiotu, które nie ma statusu zasady [d'un principe]. Ta kondycja [une condition] podmiotu nadaje sens samemu byciu i unosi jego ciężar; bycie zebrane zostaje w jedność wszechświata, a istota w wydarzenie na gruncie Sobości podtrzymujacej całe bycie. Sobość jest Sub-jectum: niesie na sobie ciężar wszechświata, jest za wszystko odpowiedzialna ${ }^{46}$.

Z drugiej strony Sobość dźwigająca cały ciężar wszechświata - co sugeruje już samo określenie podmiotu jako sub-jectum - nie jest jakimś mitycznym Atla-

\footnotetext{
${ }^{44}$ IB, s. 188 ; por. AE, s. 143.

${ }^{45} \mathrm{IB}, \mathrm{s} .244$; por. AE, s. 186.

${ }^{46}$ IB, 194-195; por. AE, s. 147.
} 
sem, lecz kimś, kto swój archetyp czerpie z postaci Cierpiącego Sługi Jahwe, o którym pisał Izajasz. Na jego postać wskazał Levinas najpierw w sposób nieco pośredni, gdy w artykule z 1963 roku Ślad Innego przedstawiał ideę odpowiedzialności jako konieczności odpowiedzi na wezwanie płynące ze strony twarzy Drugiego: „Ja nie tylko uświadamia sobie tę konieczność odpowiedzi, jakby chodziło o powinność [une obligation] czy obowiązek [en devoir], o którym miałoby decydować. Jest ono w samym swym ustanowieniu [position] na wskroś odpowiedzialnością, czyli diakonią, jak w 53 rozdziale Księgi Izajasza" ${ }^{47}$. Natomiast w sposób bardzo wyraźny do tego wątku nawiązał Levinas w Tekstach mesjanicznych. Odciął się tam najpierw od wiary chrześcijan, którzy w Cierpiącym Słudze Jahwe widzieli i ciagle widzą zapowiedź konkretnego Mesjasza, Jezusa Chrystusa. Według niego, Izajasz mówi nie o jakimś konkretnym człowie$\mathrm{ku}$, lecz ,zapowiada [...] ponad indywidualnym [l'individuel] Mesjaszem taką formę egzystencji, której jednostkowość [l'individuation] nie zawiera się w pojedynczym bycie [dans un être unique]" ${ }^{48}$. Rozwijając tę myśl, stwierdził następnie, że Mesjaszem jest każdy podmiot, każde Ja. W tym sensie jest on archetypem każdego człowieka.

Mesjasz to Ja [le Messie c'est Moi], być Ja to być Mesjaszem [être Moi, c'est être Messie]. [...] Mesjasz to sprawiedliwy, który cierpi, który wziął na siebie cierpienie innych. Któż ostatecznie bierze na siebie cierpienie innych, jeśli nie istota, która mówi „Ja” [qui dit Moi]? Fakt nieuchylania się przed ciężarem, jaki narzuca cierpienie innych, określa samą ipseitas. Wszystkie osoby [toutes les personnes] są Mesjaszem ${ }^{49}$.

W ten sposób - także poprzez odwołania o charakterze biblijnym - określając status podmiotu, status Ja, Levinas wskazywał jednak na jego wyjątkowość i jedyność, a poprzez to na jego swoistą samotność w powierzonym sobie dziele. „Ja [le Je], czyli to, co niewymienialne [le non interchangeable] par excellence, ja, czyli jedyny [l'unique], zastępuje innych. Nic nie jest gra. Na tym polega transcendencja bycia [l'être $]^{\prime 50}$.

\section{ZAKOŃCZENIE}

Trzy typy samotności, o których pisał Emmanuel Levinas, wiążą się z konkretnymi postaciami, znanymi z wielkiej literatury. Mówiąc o samotności hipostazy, odwoływał się on do tych postaw ludzkich, które spotykamy w twórczości

${ }^{47}$ Tenże, Ślad Innego, w: tenże, odkrywajac egzystencje z Husserlem i Heideggerem, thum. E. Sowa, Warszawa 2008, s. 206; por. tenże, En découvrant l'existence avec Husserl et Heidegger, Paris 1974, s. 196.

${ }^{48}$ Tenże, Teksty mesjaniczne, w: tenże, Trudna wolność, tłum. A. Kuryś, Gdynia 1991, s. 91; por. tenże, Textes messianiques, w: tenże, Difficile liberté, Paris 1976, s. 118.

${ }^{49}$ Por. tenże, Teksty mesjaniczne, dz. cyt., s. 93; por. tenże, Difficile liberté, dz. cyt., s. 120.

${ }^{50}$ IB, s. 196-197; por. AE, s. 149. 
Byrona. Być może miał tutaj na myśli zwłaszcza Giaura, samotnego nawet w klasztorze pośród mnichów szukających w swym odosobnieniu spotkania z Bogiem. Natomiast samotność separacji, nazwana przez Levinasa samotnością ateisty, a jednocześnie człowieka będącego „u siebie” (chez soi) i rozkoszującego się światem, przypomina postać Turka z ostatnich fragmentów Wolterowskiego Kandyda, który odcinał się od problemów metafizyczno-moralnych, a nawet dotyczących bieżących wydarzeń życia (w tym także politycznych), i który zalecał jedynie uprawianie ,własnego ogródka”. W ten sposób znajdował, jak twierdził, schronienie i jednocześnie zabezpieczenie przed trzema wielkimi niedolami: nudą, występkiem i ubóstwem ${ }^{51}$. Natomiast samotność Sobości wiąże się, jak to wyraźnie stwierdzał sam Levinas, z postacią Cierpiącego Sługi Jahwe.

Jednakże pisząc o tych różnych typach samotności, za każdym razem wskazywał on na możność przełamania tego stanu. Przełamanie tragicznego węzła samotności i materialności hipostazy jest możliwe, według Levinasa, tylko dzięki spotkaniu z pełną innością - a taką gwarantuje jedynie inność syna. Ojcostwo jest bowiem ,relacją z kimś obcym [avec un étranger], kto będąc całkowicie kimś innym [autrui], jest mną [moi]; jest to relacja Ja z samym sobą [du moi avec moi-même], które jednakże jest obce wobec Ja [étranger à moi]" ${ }^{2}$. Przełamanie samotności separacji i bycia na płaszczyźnie zaledwie fenomenalnej jest możliwe dzięki spotkaniu z nagą twarzą Drugiego, który będąc Mistrzem i Nauczycielem dla Ja, uczy go wolności odpowiedzialnej, wyrywając go z egzystencji polegającej jedynie na zwierzęcym rozkoszowaniu się światem.

Ta relacja - pisze Levinas w Totalité et Infini - między Drugim [Autrui] a mną [moi], rozbłyskująca w jego ekspresji, nie sprowadza się ani do liczby, ani do pojęcia. Drugi pozostaje nieskończenie transcendentny, nieskończenie obcy [étranger] - ale jego twarz, wydarzająca się jako epifania i wzywająca mnie, odrywa się od świata, który może być nam wspólny i którego możliwości, rozwijające się w naszej egzystencji, zapisane są w naszej naturze i które my rozwijamy również poprzez nasze istnienie [par notre existence $]^{53}$.

Na koniec samotność Sobości jest już od samego początku niejako naznaczona przez obecność Innego. Podmiotowość jest bowiem, według Levinasa, innym-w-Tym Samym (l'autre dans le même), a przez to natchnieniem (inspiration), lub psychicznością, która będąc Innym w Tym Samym, bynajmniej go nie alienu$\mathrm{je}^{54}$. Nawiązując do tego problemu obecności Innego w samym „sercu” podmiotu, podczas jednego ze swoich ostatnich wykładów uniwersyteckich Levinas

${ }^{51}$ Por. Wolter, Kandyd, w: tenże, Powiastki filozoficzne, thum. T. Żeleński (Boy), Warszawa 1985, s. 171-172.

${ }^{52}$ CI, s. 105 ; por. TA, s. 85.

${ }^{53}$ CN, s. 227-228; por. TI, s. 168.

${ }^{54}$ Por. IB, s. 187, 189; por. AE, s. 141-142, 143. 
stwierdził, raz jeszcze odwołując się i do Kartezjańskiej idei Boga włożonej przez Niego do naszej duszy, i do Biblii:

Chodzi tu o osobliwość „Złożoną w nas” [,mise en nous”]: „Złożenie” tego, co bezmierne [du démesuré] w wymiernym i skończonym [dans le mesuré et fini], dzięki czemu Ten Sam [le Même] podlega Innemu [l'Autre], nigdy nie będąc w stanie go osaczyć. Jest w tym jakby heteronomia, którą można także nazwać natchnieniem [inspiration] - i posuniemy się nawet do mówienia o proroctwie, które nie jest jakąś genialnością, lecz właśnie duchowością umysłu [la spiritualité même de l'esprit]. To sens z wersetu Amosa: „Przemówił Bóg, któż nie będzie prorokować?” [Am 3,8] jakby proroctwo polegało tylko na tym, że ma się słuch ${ }^{55}$.

Wskazywanie przez Levinasa na możliwość przełamania samotności we wszystkich jej postaciach - hipostazy, separacji i Sobości - stanowi niewątpliwie nie tylko o jego wierze w człowieka, ale jest jednocześnie współczesnym potwierdzeniem starożytnego powiedzenia o człowieku jako animal sociale.

\section{BIBLIOGRAFIA}

Jonas H., Idea Boga po Auschwitz. Żydowski głos, w: tenże, Idea Boga po Auschwitz, tłum. G. Sowinski, Kraków 2003, s. 31-46.

Levinas E., Le temps et l'autre, Paris 2007.

Levinas E., Czas i to, co inne, thum. J. Migasiński, Warszawa 1999.

Levinas E., De l'évasion, „Recherches Philosophiques” 5(1935-1936), s. 373-392.

Levinas E., De l'évasion, Saint-Clément-de-Rivière 1982.

Levinas, E., O uciekaniu, thum. A. Czarnacka, Warszawa 2007.

Levinas E., Totalité et Infini, La Haye 1974.

Levinas E., Całość i nieskończoność, thum. M. Kowalska, Warszawa 1998.

Levinas E., Autrement qu'être ou au-delà de l'essence, La Haye 1974.

Levinas E., Inaczej niż być lub ponad istota, tłum. P. Mrówczyński, Warszawa 2000.

Levinas E., Ślad Innego, w: tenże, Odkrywajac egzystencję z Husserlem i Heideggerem, thum. E. Sowa, Warszawa 2008, s. 197-214.

Levinas E., En découvrant l'existence avec Husserl et Heidegger, Paris 1974.

Levinas E., Textes messianiques, w: tenże, Difficile liberté, Paris 1976, s. 83-129.

Levinas E., Teksty mesjaniczne, w: tenże, Trudna wolność, tłum. A. Kuryś, Gdynia 1991, s. 61-100.

Levinas E., Dieu, la mort et le temps, Paris 1993.

${ }^{55}$ E. Levinas, To Samo i Inne, wykład z dnia 12 XII 1975, w: tenże, Bóg, śmierć i czas, tłum. J. Margański, Kraków 2008, s. 164-165. 
Levinas E., To Samo i Inne, wykład z dnia 12 XII 1975, w: tenże, Bóg, śmierć i czas, tłum. J. Margański, Kraków 2008, s. 164-170.

Wolter, Kandyd, w: tenże, Powiastki filozoficzne, tłum. T. Żeleński (Boy), Warszawa 1985, s. $91-172$.

\begin{abstract}
Solitude is, to some measure, in the centre of Emmanuel Levinas's philosophy. Indeed, in each of the three periods of his philosophical path, solitude adopts a different shape. In the first period, Levinas shows us hypostasis as the solitude of the monad, tragically enclosed within itself. In the second period he sketches before our eyes the image of solitude as a transcendental condition of the occurrence of encounter with the Other. Whereas in the third period, he asserts the solitude of the subject who is infinitely responsible for Others. Admittedly, the term "solitude" (la solitude) appears only in the first period of his philosophical quest. In the second period, he designates solitude by the terms "separation" (la séparation), while in the third period he calls it "selfness" (le Soi). Although Levinas uses those three distinct terms, which might suggest completely different realities, they converge precisely in what constitutes the substantial richness of the experience of solitude.
\end{abstract}

\title{
Keywords
}

hypostasis, solitude, materiality, separation, delight, election in anarchic time, infinite responsibility for the Other

\section{Słowa kluczowe}

hipostaza, samotność, materialność, separacja, rozkoszowanie się, wybranie w czasie anarchicznym, nieskończoność odpowiedzialności za Innego 